\title{
What Are the Attractiveness Factors That Influence the Choice of a Tourist Destination—A Study of Brazilian Tourist Consumer
}

\author{
Laerte Gil Nicaretta Oliani \\ Universidade São Caetano do Sul, São Paulo, Brazil \\ George Bedinelli Rossi \\ Escola Superior de Propaganda e Marketing, São Paulo, Brasil \\ Universidade de São Paulo, São Paulo, Brasil \\ Viviane Chunques Gervasoni \\ Universidade São Caetano do Sul, São Paulo, Brasil
}

\begin{abstract}
This paper results from an exploratory investigation regarding the tourist consumer behavior identifying which attractiveness factors from tourist destination define tourist consumer capacity and have importance in his choice. In this investigation, a model elaborated based on a detailed situational analysis considering different aspects related with offering and demand that compose the tourist activity dimensions, such as infra structure, tourism potential, geographical factors, climate, economy, cultural and environmental resources public policies and sustainability was adopted. The competitive environment also was analyzed, once tourists have different destinations to their disposal which is attracted for destinations that offer optimum value and the greatest number of benefits. To reach the proposed objectives, an exploratory research through in depth personal interviews with 20 individuals was carried on using snow ball technique aims to identify the possible factors of attractiveness and related degree of importance of each of these possible factors in the tourist consumer behavior. After that, a confirmatory research was conducted with 150 individuals. The sampling process was done using convenience sample and data which were collected between November and December, 2009, through direct proportionally survey divided between man and woman.
\end{abstract}

Keywords: attractiveness factors, tourist cluster, tourist choice, tourist destination, sustainability

\section{Literature Review}

\section{Tourist Consumer Behavior}

The behavior of the consumer of the tourist product in the process of decision taking is influenced by a series of deterministic and internal and external motivators' factors. And, according to Swarbrooke and Horner (2002), these factors, in general, are not quantified.

In that sense, Beni (2006) states that the purchase decision regarding a tourist product results from a complex

Laerte Gil Nicaretta Oliani, Master, Universidade São Caetano do Sul.

George Bedinelli Rossi, Ph.D., Escola Superior de Propaganda e Marketing, Universidade de São Paulo.

Viviane Chunques Gervasoni, Master, Universidade São Caetano do Sul. 
process in which consumer is influenced by internal and external factors. And as internal factors, there are personal motivators, personality income disposal, wealth, family and professional commitments, past experiences, hobbies and personal interests, knowledge of holidays, life style and attitudes, opinions and perception process regarding information received.

For external factors, there are products adequacy availability, trip agents advices, information received from destination, tourism organizations, transport firms to take consumer from home to destination, family and friends word of mouth recommendations, health issues, special promotions offerings from tourism organizations and destination clime (Beni, 2006).

For identification of these internal and external factors, first the tourism is defined as an elaborated and complex decision process on what to visit, where, how and how much to pay for. Personal and social accomplishments as emotional, economic, cultural, ecological and scientific nature have influence in this process regarding the choice of the destination, the time of permanence, the kind of used transports systems, the type of lodging and the objective of the trip in itself for the material exploitation as subjective dreams, desires of projective imagination, enrichment of existential historic-humanistic, professional and businesses expansion. It adds that tourists' needs are heterogeneous, and the satisfaction degree of value for them perceived varies in accordance with what the service lender provided for that definitive customer (Kotler, 1994).

It also can be said that the tourism market can be segmented by the type of attraction that the tourists look for as natural beauties, sun, adventure, game, events/sports and cultural/history, or places, regions, season of the year, characteristics of the customers and benefits. It suggests for tourism agents to identify and understand the values that the tourists search as users (performance, social and emotional values), as consumers (convenience and personalization) and as people who pays for something (price and credit). The competitive environment also needs meticulously to be analyzed. The tourists have, literally, thousand of destinations available to them. They will be attracted to destinations they believe will offer optimum value to them, either in reason of the biggest number of benefits (attractions, prestige, etc.), either because they are cheaper or more accessible (Beni, 2006).

Cooper et al. (2001) state that it is important to understand that the management of tourism will not be efficient without an understanding of the form for which the consumers make decisions and act in relation to the consumption. Therefore, the tourist product is a service with intangibilities characteristics, perishability, inseparability, heterogeneities and inexistence of property.

Thus, it is observed that the tourism industry is an economic activity involving a complex networking of factors as geographic location, history, language, climate, levels of economic development, quality of the rural and urban landscapes, public policies, degree of economic and political stability, types of lodging and transportation system development.

Therefore, the definition of the factors represents an important source of information for the establishment of standards of customer satisfactions, measuring quality, controlling the interactions of the process and specifying marketing policies.

Cooper et al. (2001) and Porter (2004) display that the tourist marketing will become more effective if develop a more integral understanding of what has influence on purchase behavior of the tourist consumer. This requires an evaluation on how consumers behave and how they recognize specific trip needs, search information and evaluate them, make acquisitions and later how they evaluate the tourist experience. This identification 
process, development and attainment of these attributes becomes a competitive advantage, and its objective is the execution of the most important chain value activities cheaper, or better, that the competition, being the heart of performance of a company in competitive markets.

In the tourism context row materials are natural, cultural and environmental factors that are tied up to touristy demand. So, in that sense, the decision consumer process takes into account physical, environmental and clime factors surrounding each destination (Munoz, 2007) and Beni (2006) complements tourism cluster definition as a set of attractive factors with high tourist differentiation, concentrated in a specific limited geographical space with high quality equipments and services, collective efficiency with political and social cohesion, articulated chain value and associative culture, and with high management standards in a networked firms that generate comparative and competitive strategic advantages.

\section{Tourism Attractiveness}

The attractiveness of a tourism destination concept is a new investigation issue rooted in Gearing, Swart and Var's (1974) findings. Others authors as Ritchie and Zins (1978), joined Gearing, analyzing how culture is related to attractiveness of a tourism location.

Several researchers as Ferrario (1979), Formica and Uysal (2006), Hu and Ritchie (1993), Kim (1998), Klenosky (2002), Kobotis and Vassiliadis (2001) and Meinung (1995) had proposed that destination attributes quantity is a key determinant factor for destination attraction. Those attributes include all kind of attractions as natural, artificial, physical and social, pricing level, historical, fairs and shopping. For Middleton (1989) and Vengesayi (2008), the most important attractiveness attributes are characteristics, lodging prices and transports networking. And for Formica (2002), the attractiveness of a tourism destination is many times described as the opinion of the visitors perceived through the capacity to satisfy theirs needs.

Gartner (1989) identifies and includes other attributes of attractiveness such as local cultural and historical, nocturnal life, natural environmental and receptivity amongst others. Meinung (1995) argues that the landscape is one of the most important attributes to attract tourist, while cultural attributes will grow together in importance with the world-wide demand for tourism. For Hu and Ritchie (1993), the attractiveness depends on the context of the vacation experience and that one determined potentially negative attribute of the destination is more acceptable for determined types of vacation, work and study, than another one as leisure (Vengesayi, 2008).

Researchers as Vaz (2002) among others have studied attractiveness of the tourist destination, identifying the attributes with the biggest factor of influences and grouping them in distinct groups, determined as main factor attraction. In this sense, factor of tourist attractiveness is the element that exerts significant influence in the decision of a tourist who includes natural resources, cultural, religiosities, cultural goods, and sportiveness and events resources. Thus, for the establishment of the positioning in the degree of attractiveness inside the tourist destination, it is important to identify the role played to capture demand and consequently its importance, classifying them as main, complementary factors of attractiveness, of entertainment and support. The identification of the degree of attractiveness of a destination and its classification are basic for the strategy of a locality in terms of partnerships in tourist cluster.

\section{Tourist Cluster}

According to Porter (1989), industrial agglomerations consist of companies and organizations, formal or 
informal, geographically concentrated and interrelated with common and complementary bonds. This approach for industrial agglomerations adapt it to tourism as an economic sector where for the demand, the consumers are those who need to travel for another localization, that not its place of residence, for the purchase and use of the tourism goods and services. Li, Wong, Song and Witt, (2006) and Munoz (2007) state that analyzing by demand side, the tourist destination has a priori and accumulated quota of row materials that can not be transferred to another place for the production of the tourist demand. In this context, row materials are natural, cultural and environmental factors that are strongly tied up to the demand of the tourism. The decision processes taking into account by the consumer is based, amongst other factors, on physical characteristics, climatic and environmental factors surrounding each dimension.

Beni (2003) defines tourist cluster as a set with distinguishing attractive factors, concentrated in a delimited geographic space endowed with high quality equipment and services, collective efficiency, social and politics cohesion, joint productive chain and associative culture, and with excellency management in networked companies who generate comparative and competitive strategic advantages. Lanza and Pigliaru (1994, 2000) state that the activity of tourism tends to be stronger in regions highly specialized in tourism and the construction of interrelated resources is a key factor to impose strong growth of demand.

\section{Investigation Dimensions}

For this study, a constructed model was adopted on the basis of a detailed situational analysis, taking in consideration different aspects related with offer and demand that the dimensions of the tourist activity compose.

Being based on "general conceptual model of destination competitiveness" of Ritchie and Grouch (Grouch, 2006), analyses related with infrastructure, tourist potential, geographic factors, climatic factors, economy, environmental resources and cultural, public politics and support, were included aiming to quantify the importance degree and influences of these factors in the tourist consumer decision making process to choose destination.

The above factors are divided in 08 attractiveness sub-factors:

(1) Geographical location;

(2) Clime;

(3) History and regional tradition;

(4) Quality of the natural resources as beach, mountain, forest, snow, and quality of the urban resources;

(5) Architecture considering museums, thematic parks, shopping centers, and shows, public policies, embracing: (a) security; (b) basic sanitation; and (c) illumination;

(6) Means and amount of lodging as hotels, resorts and motels;

(7) Development of means of transport to reach destination such as airplanes, roads, trains, and ships;

(8) Time to get to destination, trip time, making possible to facilitate its visualization and understanding for the respondents.

The attractiveness factors had been evaluated in its importance in accordance with a Likert type scale with 7 points varying from " 1 -Not important at all” to "7—Extremely important".

\section{Research Problem}

For Hu and Ritchie (1993), a tourist destination is an attributes combination that includes all types of 
attractions as natural, pricing levels, historical attractions, purchases, and festivals. Thus, the research problem is: Which are the factors that influence in the choice of the tourist destination for the consumer?

And, Formica (2002) states that the attractiveness of a tourist destination is many times cited as the opinion of the visitors regarding the capacity of the destination to satisfy consumers' needs and that the attractiveness studies are necessary to understand the elements that stimulate the people to travel and to know a specific region.

Thus, in this study a model of attractiveness was elaborated relating the aspects most important in the experience of the tourist, being based on "general conceptual model of destination competitiveness" of Ritchie and Grouch (Grouch, 2006). In this sense, the objective of this inquiry is to evaluate the degree of importance of the factors identified that influence the consumer choice regarding tourist product (Malhotra, 2002; Geertman \& Van Eck, 1995; Han, Durbarry, \& Sinclair, 2006).

\section{Methodology}

Considering the above objectives, an exploratory study, qualitative nature, was carried on through in depth interviews with 20 individuals, type snow ball, aiming to identify possible factors of attractiveness and its degree of importance in consumer behavior with a script based on literature review (Bardin, 2002). According to Malhotra (2001) these interviews can be of great validity when the research problems demand detailed understanding of a behavior, providing an analysis and personal understanding.

After that, a descriptive research with 150 individuals was realized. A convenience sample was carried on and the collection of data was carried through November to December, 2009, and through the instrument of research was applied proportionally between men and women.

Questionnaires had been applied where each interview judged the 08 factors in accordance with a Likert scale, varying " 1 - Totally unimportant" to "7—Extremely important". The attributed notes had been weighed and the final sum resulted in general averages for each attribute of attractiveness.

\section{Findings}

The respondents had evaluated the importance of each factor, attributing to them a value. Table 1 presents the results gotten for attractiveness factors and the corresponding average.

Respondents profile:

(1) Age:

- 36-40 years: $20.55 \%$

- $41-45$ years: $17.95 \%$

- 45-50 years: 25.64

- over 50 years: $20.51 \%$

(2) Married or single:

- married: $65.79 \%$

(3) Number of children:

- no (zero) children: $35.78 \%$

- 02 (two) children: 35.90\%

(4) Educational level:

- College education: $91.89 \%$ 
(5) Monthly income:

- over US\$ 4500: 52.63\%

Table 1

Attractiveness Factors Importance

\begin{tabular}{ll}
\hline Attractiveness & Average \\
\hline a. Geographycal location & 1.53 \\
b. Clime & 1.21 \\
c. History and regional tradition & 0.95 \\
d. Quality of natural resources & 1.68 \\
d.1 beach & 1.22 \\
d.2 mountain & 0.82 \\
d.3 forest & 0.65 \\
d.4 snow & 0.59 \\
e. Quality of urban resources & 1.26 \\
e.1 arquitecture & 0.94 \\
e.2 museums & 1.00 \\
e.3 thematic parks & 1.06 \\
e.4 shoppings centers & 0.31 \\
e.5 theaters and shows & 0.69 \\
f. Public policies (security, basic sanitation and illumination) & 1.28 \\
g. Means and amount of lodging as hotels, resorts and motels & 1.61 \\
h. Development of means of transport to reach destination such as airplanes, roads, trains, and ships & 1.72 \\
i. Time to get to destination & 0.67 \\
\hline
\end{tabular}

Note. Source: The authors.

It has been distinguished the degree of importance with averages above 1.5 (of the total of 2) the relative attractiveness of geographic location; quality of the natural resources; lodging (hotels, inns, resorts) and development of transport means to arrive to destination (airplane, roads, train, ship).

It is important to state out that the attractiveness regarding quality of the natural resources had 1.68 average, and its subdivisions had had inferior averages as beach, 1.22; mountain, 0.82; forest, 0.65 and snow, 0.59; that is, these factors are not high in importance. The same occurred for the attractiveness in regards to quality of urban resources that had average 1.26; and its subdivisions had had inferior averages as architecture, 0.94; museums, 1; thematic parks, 1.06; shopping centers, 0.31 and theaters and shows, 0.69 .

Concerning the attractiveness with minor average, it can be stated that time to destination (trip time) with 0.67 is the lowest one.

In ranking of classification of relevance, the attractiveness that had presented greater importance, according to respondents was: In first place, development of the ways of transport to arrive to destination (airplane, roads, train, ship); In second, quality of the natural resources; In third, lodging (hotels, inns, resorts) and in fourth, geographic location.

\section{Final Consideration}

The elaboration of this article was motivated to understand the behavior of the tourist consumer, identifying which are the factors of attractiveness of the tourist destinations that define its potentiality and influence in the choice of the tourist consumer.

The identified most important factors in this research regarding the process purchase of the tourist product, according to interviewed individuals, related to attractiveness attributes, distributed by importance order are: 
development of the means of transport to arrive the destination (airplane, roads, train, ship); quality of the natural resources; lodging (hotels, inns, resorts); geographic location; quality of the urban resources; public policies (security, basic sanitation, illumination); climate; history and regional tradition and time to get to destination (trip time). These attributes are follow commented.

The research done by personal interviews indicated the attractiveness items considered by the tourist consumer and they had served of base for the descriptive research. This disclosed that the most important item for the choice of the consumer is the easiness of access to the tourist destination. Thus, the bigger the option of choices of transport to the available to consumer the more the consumer will tend to prioritize this destination.

The second most important item is related with the characteristics of the destination, in special, the variety of natural attractions presented as quality of natural resources as beaches and similar.

After that, to rest presented as lodging is the third most important item. In this sense, the offer of where to rest is an important factor for the election of the tourist destination. Interesting to observe that geographic location is a relevant factor, however, of average importance in the sense that the offer of locomotion or transport, the characteristics of the place and the variety of places to rest are more important than location. This supplies evidences of the geographic place that presents moderate importance.

The importance of urban resource is a factor that influences the choice of where to go. If the place does not present minimum cares of maintenance the tourist consumer may not go to this place. That is, the care and the maintenance of the urban area are factors that must be taking into account.

After that, the public policies as security, basic sanitation and illumination are factors raised for the election of the tourist destination. Thus, the risks to the health of the consumer tourist and the perception of physical security do have influence in consumer's choice.

The research disclosed that factors as climate, history and regional tradition present low degree of influence in the process of decision of tourist consumer. Most interesting is that the data of the research indicates that the time of displacement until the destination point is the factor of lesser importance. Thus, the data supply evidences that the consumer tourist is willing to undertake ample efforts of trip time to arrive at the point of his preferred tourist destination.

Regarding sustainability, factors as history and regional tradition, mountain, forest, public policies present low degree of influence in the process of purchase decision, observing that the consumer at no moment of the research revealed concern about this issue.

For clusters analysis, it is distinguished that the development of the ways of transport to arrive to the destination together with means of lodging presented a high degree of importance in the choice of the tourist destination.

\section{Limitations and Suggestions for Future Research}

It is important to notice that some inherent limitations to the adopted methodological procedures exist, as the sample taken. The study represented a sample with a medium income that by itself restricts results generalization. Also, as there are wide differences in perceptions, styles, and behaviors, it is suggested for future research an investigation considering profession, age variation and marriage diversification. 


\section{References}

Beni, M. C. (2003). Globalização do turismo: Megatendências do setor e a realidade brasileira. São Paulo: Aleph.

Backwell, R. D., Miniardi, P. W., \& Engel, J. F. (2005). Comportamento do consumidor. São Paulo: Cengage Learning,.

Balanzá, I. M., \& Nadal, M. C. (2003). Marketing e Comercialização de Produtos Turísticos. São Paulo: Pioneira Thomson Learning.

Balarguer, J., \& Cantavella-Jordá. (2001). Examining the export-led growth hypothesis for Spain in the last century. Applied Economics Letters, 8.

Balarguer, J., \& Cantavella-Jordá. (2002). Tourism as a long-run economic growth factor: The Spanish case. Applied Economics, 34.

Bardin, L. (2006). Análise de Conteúdo. Lisboa: Edições70.

Beni, M. C. (2006). Analise estrutural do turismo. São Paulo: Senac.

Cooper, C., et al. (2001). Turismo—Princípios e práticas. Porto Alegre: Bookman.

Crouch, G. (2006). Destination competitiveness: Insights of attribute importance. International conference of trends, impacts and policies on tourism development, Crete.

Cunha, S. da, \& Cunha, J. C. da. (2005). Competitividade e Sustentabilidade de um Cluster de Turismo: uma Proposta de Modelo Sistêmico de Medida do Impacto do Turismo no Desenvolvimento Loca. RAC, 9 (esp. 2).

Durbarry, R. (2004). Tourism and economic growth: The case of Mauritius. Tourism Economics, 10.

Filippini, R. (2006). Strumenti statistici per l'analisi esplorativa dei sistemi turistici locali. Dipartimento di Scienze Statistiche, Università di Bologna.

Formica, S. (2002). Measuring destination attractiveness: A proposed framework. Journal of American Academy of Business, 1(2).

Gearing, C. E., Swart, W. S., \& Var, T. (1974). Establishing a measure of touristic attractiveness. Journal of Travel Research, 12(4).

Geertman, S. C. M., \& Van Eck, J. R. R. (1995). GIS and models of accessibility potential: An application in planning. International Journal of Geographical Information Science, 9, 67-80,.

Gil, A. C. (2009). Como elaborar projetos de pesquisa. São Paulo: Atlas.

Han, Z., Durbarry, R., \& Sinclair, MT. (2006). Modelling US tourism demand for European destinations. Tourism Management, 27, 1-10.

Hu, Y., \& Ritchie, B. J. R. (1993). Measuring destination attractiveness: A contextual approach. Journal of Travel Research, Fall.

James, F. E., et al. (2000). Comportamento do Consumidor. Rio de Janeiro: Livros Técnicos e Científicos.

Kim, H. J., \& Chen, M. J. S. (2006). Tourism expansion and economic development: The case of Taiwan. Tourism Management, 27.

Kotler, P. (2000). Administração de marketing. São Paulo: Prentice Hall.

Kotler, P., Haider, D., \& Rein, I. (1994). Marketing público: como atrair investimentos, empresas e turismo para cidades, regiões, estados e países. São Paulo: Makron Books.

Krippendorf, J. (2000). Sociologia do Turismo. Para uma nova compreensão das viagens. São Paulo: Aleph.

Krugman, P. (1995). Development, geography, and economic theory. Boston, MA: The MIT Press.

Lanza, A., \& Pigliaru, F. (1994a). The tourism sector in the open economy. Rivista Internazionale di Scienze Economiche e Commerciali, 41.

Lanza, A., \& Pigliaru, F. (1994b). Tourism and economic growth: Does country’s size matter? Rivista Internazionale di Scienze Economiche e Commerciali, 47.

Li, G., Wong, K., Song, H., \& Witt, S. (2006). Tourism demand forecasting: A time varying parameter error correction model. Journal of Travel Research, 45.

Meng, F., Tepanon, Y., \& Uysal, M. (2008, January). Measuring tourist satisfaction by attribute and motivation: The case of a nature-based resort. Journal of Vacation Marketing, 14(1), ABI/INFORM Global.

Monfort, M. V. M. (2009). Competitividad y factores críticos de éxito en la "hotelería de litoral”: Experiencia de los destinos turísticos Benidorm y Peñíscola. Tesis Doctoral—Universidad de Valência—Espanha: Biblioteca Virtual Miguel Cervantes, FITUR /IFEMA. 2000. Retrieved from http:// www.cervantes.com/fichaobra.htlm?Ret=2619

Mota, K. C. N. (2001). Marketing turístico. São Paulo: Atlas.

Munoz, T. G. (2007). German demand for tourism in Spain. Tourism Management, 28.

Porter, M. E. (1990). The competitive advantage of nations. New York: The Free Press.

Porter, M. E. (1998). On competition. Boston, MA: Harvard Business School.

Rosenfeld, S. A. (1997). Bringing business clusters into the mainstream of economic development. European Planning Studies, 5.

Ruschmann, D. V. M. (2001). Turismo e planejamento sustentável: A proteção do meio ambiente (7th ed.). Campinas: Papirus.

Swarbrooke, J., \& Horner, S. (2002). Comportamento do consumidor no turismo. São Paulo: Aleph.

Vaz, N. G. (1999). Marketing turístico. São Paulo: Pioneira.

Vengesayi, S. (2008). Destination attractiveness: Are there relationships with destination attributes. The Business Review, Cambridge, 10(2).

World Economic Forum (WEF). (2008). The travel and tourism competitiveness report 2008. Furthering the process of economic development. Genebra, Suíça. 